Transport and Communications Science Journal

\title{
MEASURING THE SUCCESS LEVEL OF PUBLIC-PRIVATE PARTNERSHIP TRANSPORTATION INFRASTRUCTURE PROJECTS IN VIETNAM USING FUZZY TOPSIS METHOD
}

\author{
Le Dinh Thuc ${ }^{1}$, Pham Phu Cuong ${ }^{2 *}$ \\ ${ }^{1}$ Pukyong National University, 45 Yongso-ro, Namgu, Busan, South Korea \\ ${ }^{2}$ Campus in Ho Chi Minh City, University of Transport and Communications, 450 - 451 Le \\ Van Viet Street, Tang Nhon Phu A Ward, District 9, Ho Chi Minh City, Vietnam
}

\author{
ARTICLE INFO \\ TYPE: Research Article \\ Received: $26 / 3 / 2020$ \\ Revised: $17 / 5 / 2020$ \\ Accepted: 18/5/2020 \\ Published online: 28/5/2020 \\ https://doi.org/10.25073/tcsj.71.4.9 \\ * Corresponding author \\ Email: ppcuong@utc2.edu.vn ; Tel: (+84)0903.787.362
}

\begin{abstract}
Public-Private Partnership (PPP) has emerged as an effective procurement in delivering infrastructure and public service in many countries over the world since last few decades. It brought more benefits for sustainable development compared to traditional procurement in many developing countries. However, in order to determine whether a project is successful or not has still remained an ambiguous perception. Therefore, this study will rank the successful level for PPP transportation infrastructure projects in Vietnam via case studies. Fifteen success criteria were identified by the comprehensive review. The fuzzy TOPSIS method was then applied to evaluate and rank the success level for case studies. The result showed that project 2 is considered as the most successful until this recent time with a satisfactory degree of 0.489 . Project 1 and project 3 are ranked second and third with a satisfactory degree of 0.482 and 0.435 , respectively. Although the projects were judged as effective. Nevertheless, the success index of these expressway project still lower than 0.5 . Therefore, project managers need to propose effective solutions to improve the success of these projects in the future. This result can help participants to be a good insight into the PPP project success in developing countries in general and Vietnam in particular.
\end{abstract}

Keywords: public-private partnership, transportation projects, success level, fuzzy TOPSIS, Vietnam. 


\section{INTRODUCTION}

Public-Private Partnership (PPP) has emerged as an effective procurement in delivering infrastructure and public services in many developing countries since last few decades. PPP form is a participation of both public and private parties in the project based on their expertise with different levels of contribution and commitment in delivering public services effectively [1]. The experience and knowledge of private sector were exploited via PPP investment [2]. PPP schemes brought advantages in procurement and risk-sharing between the parties [3]. In Vietnam, a number of transportation projects, especially expressway projects have implemented via PPP procurement since 1993 [4], which contributed to enhancing infrastructure service and the economic market. Nevertheless, not all PPP projects are successful. Many challenges have been occurred in some projects in developed and developing countries. BOT transportation projects in Thailand, the Sydney Cross City Tunnel, and the Betuwe Railway in the Netherlands were examples of the failure of PPP procurement [5-7]. Therefore, many prior authors focused on several topics of the PPP market such as risk management, critical success factors, value for money, economic feasibility, government role, and concessionaire selection [8] However, studies on successful level of PPP projects is scarce $[9,10]$. In fact, it will be difficult for private and public sectors to define whether their projects have been successful or not if success criteria are not considered [11]. Therefore, this study will rank successful level for PPP transportation projects in Vietnam via three expressway projects. This study will help both practitioners and researchers to have an in-depth understanding of the criteria to make good decisions for the success of PPP transportation projects in this country.

\section{LITERATURE REVIEW}

The definition of project success is complex [12]. It depends on project type and project participants, etc [13]. Al-Tmeemy et al.[14] revealed that project success is a consensus of project efforts and objectives of enterprises. Success is described as an intangible measurement [15]. Determining whether a project is considered successful or not has still remained an ambiguous perception [16]. In this context, Chan and Chan [13] concluded that a successful project needs to adhere to specific principles to gain favorable outcomes. In another context, PPP nature is more complex due to the huge amount of investment and longterm contractual periods [17]. Therefore, many authors have sought different ways to gain success for PPP projects. Akintoye et al. [1] implied that there are differences in success criteria between PPP projects and traditional projects. Tam [18] denoted that completion in time and budget, service quality, well-structured agreement, and an equitable legal system as important components for BOT project success in Southeast Asia. Yuan et al.[19] analyzed 15 successful objectives in PPP projects based on the opinions of different stakeholders. Whereby, project quality, reliability service, and completion in the budget was ranked the top three performance objectives in PPP projects. Similarly, Mladenovic et al. [20] established two layers for performance evaluation of PPP transportation projects based on a brainstorming approach. They revealed that PPP project success should be defined in the accomplishment of the ultimate objectives of different stakeholders in the first stage, including profitability, stakeholders' satisfaction, value for money, effectiveness, environmental influence, and level of service. The fulfillment of the performance objectives of each stakeholder will be examined in the second stage for assessing whether the project is successful or not. Romero and Liyanage [21] proposed 29 performance measures and 9 key 
performance indicators to define the success level in PPP road projects in Europe with testing of 13 road projects in the UK, Spain, Belgium, Portugal, Netherlands, and Greece. In another review, deriving from the international experts' judgment from Hong Kong and Ghana, OseiKyei and Chan [11] collected 15 critical success criteria of PPP projects in which seven success criteria are considered as very critical such as meeting standard output, adherence to budget, adherence to time, profitability, effective risk management, service quality, and environmental performance.

The concept of project success is diverse and ambiguous due to various perceptions [15]. Nevertheless, the contribution of previous studies regarding successful measurement for PPP projects is limited [22]. The present study, therefore, enriches refer source of this topic by identifying success criteria and evaluating project success via case studies in Vietnam.

\section{RESEARCH METHODOLOGY}

\subsection{Identifying success criteria for PPP projects}

A literature review relevant to success criteria in both traditional construction and PPP projects has been carried out via the previous studies, by which 15 success criteria were identified. To ensure the adequacy of this research, the obtained criteria were sent to a group of five experts who had at least ten years of experience in PPP transport projects in Vietnam. Each expert was asked to examine the suitability of success criteria for PPP transport projects based on his/her experience. In this process, five experts agreed with most criteria, a few criteria were accepted by some experts but not all. They then concentrated to judge these criteria for accomplishing the list. Finally, total a list of 15 success criteria was adopted by the consensus of five experts and no criteria were suggested to add to the list. They are presented in Table 1.

Table 1. Success criteria for PPP projects.

\begin{tabular}{|c|c|c|c|c|c|c|c|c|c|c|c|}
\hline & [9] & [11] & [18] & [23] & [24] & [15] & [13] & [25] & [26] & [27] & {$[22]$} \\
\hline Minimized contract disputes & & $\mathrm{X}$ & & & & & & & & & \\
\hline Effective risk management & & $\mathrm{X}$ & & & & & & $\mathrm{X}$ & & & \\
\hline Technology transfer & & $\mathrm{X}$ & & & & & $\mathrm{X}$ & $\mathrm{X}$ & & & \\
\hline Health and safety & & & & & $\mathrm{X}$ & $\mathrm{X}$ & $\mathrm{X}$ & $\mathrm{X}$ & & & \\
\hline Long-term partnership & & $\mathrm{X}$ & & & & & & & & & \\
\hline Stakeholder satisfaction & $\mathrm{X}$ & & & $\mathrm{X}$ & & $\mathrm{X}$ & $\mathrm{X}$ & $\mathrm{X}$ & $\mathrm{X}$ & $\mathrm{X}$ & $\mathrm{X}$ \\
\hline Completion in budget & $X$ & $\mathrm{X}$ & $\mathrm{X}$ & $\mathrm{X}$ & $\mathrm{X}$ & $\mathrm{X}$ & $\mathrm{X}$ & $X$ & $X$ & & $\mathrm{X}$ \\
\hline Completion on time & $\mathrm{X}$ & $\mathrm{X}$ & $\mathrm{X}$ & $\mathrm{X}$ & $\mathrm{X}$ & $\mathrm{X}$ & $\mathrm{X}$ & $\mathrm{X}$ & $\mathrm{X}$ & & $\mathrm{X}$ \\
\hline Profitability & & $\mathrm{X}$ & & $X$ & & $X$ & $\mathrm{X}$ & & & & \\
\hline Local economic development & & $\mathrm{X}$ & & & & & & & & & \\
\hline Achievement Value for Money & $\mathrm{X}$ & & & $\mathrm{X}$ & & & & & & $\mathrm{X}$ & \\
\hline Quality of service & $\mathrm{X}$ & & $\mathrm{X}$ & $\mathrm{X}$ & $\mathrm{X}$ & $\mathrm{X}$ & $\mathrm{X}$ & $\mathrm{X}$ & $\mathrm{X}$ & & $\mathrm{X}$ \\
\hline Productivity & & & & & & $\mathrm{X}$ & & & & & \\
\hline Environmental impact & & & & & & $\mathrm{X}$ & $\mathrm{X}$ & $\mathrm{X}$ & & & \\
\hline Equitable legal system & & & $\mathrm{X}$ & & & & & & & & \\
\hline
\end{tabular}

Source: [9] = Aham et al., (2018); [11] = Osei-Kyei and Chan, (2017); [18] = Tam, (1999); [23] = Zayyanu and Johar, (2017); [24] = Lim and Mohamed, (1999); [15] = Chan et al., (2002); [13] = Chan and Chan, (2004); [25] = Ahadzie et al., (2008); [26] = Baccarini, (1999); [27] = Liu et al., (2017); [22] = Liyanage and Romero, (2015). 
Transport and Communications Science Journal, Vol. 71, Issue 4 (05/2020), 403-418

\subsection{Evaluating and ranking the success level of PPP transportation projects using fuzzy TOPSIS method}

\subsubsection{Fuzzy theory}

Decision-makers need to handle complex problems under the context of uncertainty in the construction industry [28]. The decision-makers play a important role for calculating, selecting or ranking the alternatives [29]. Therefore, fuzzy theory was introduced the first time by Bellman and Zadeh [30] to solve uncertainty issues. Until recently, many studies extended fuzzy methods through the fuzzy environment for decision making in construction industry [31,32]. In these methods, fuzzy TOPSIS was considered as a reasonable application in the decision-making process using fuzzy linguistic evaluation via multiple experts' opinions [33]. Maghoodi and Khalizadeh [34] applied the fuzzy TOPSIS method to rank the critical success factors of the construction projects in Iran. The finding of Tan et al. [35] assisted contractors in-depth understanding of making better decisions on project selection. Azari et al. [36] developed fuzzy TOPSIS techniques to select the risk assessment model for decision making of construction corporations in Iran. Therefore, fuzzy TOPSIS can be adopted in this paper to rank the importance of the performance measurement in each phase over PPP project life-cycle. Some basic definitions of fuzzy set theory are viewed as follows:

Concept 1 . A fuzzy number $\alpha$ belong to $R$ is decribled by membership function $f_{\alpha}(x)$ which is defined the score of membership of $x$ in $\alpha: \alpha=\left\{\left(x, f_{\alpha}(x)\right) \mid x \in R: R \rightarrow[0,1]\right\}$ [37].

Concept 2. A triangular fuzzy number $\alpha=\left(x_{1}, x_{2}, x_{3}\right)$ is established (see Fig. 1). The membership function of fuzzy number $\alpha$ is determined as [37]:

$$
f_{\alpha}(x)=\left\{\begin{array}{c}
0, x \leq x_{1} \\
\frac{x-x_{1}}{x_{2}-x_{1}}, x_{1} \leq x \leq x_{2} \\
\frac{x_{3}-x}{x_{3}-x_{2}}, x_{2} \leq x \leq x_{3} \\
0, x>x_{3}
\end{array}\right.
$$

Where $x_{1}, x_{2}, x_{3}$ represent for left, mean, and right bound real values in a triangular fuzzy number, respectively.

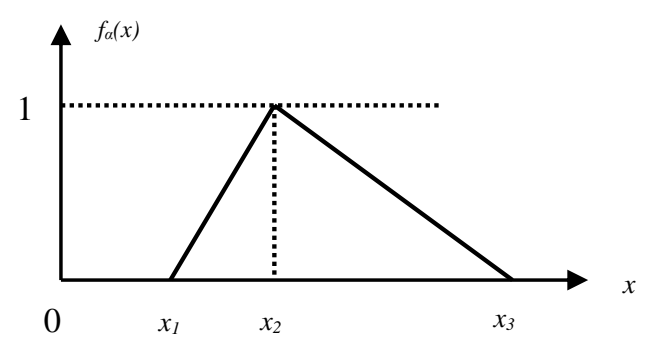

Figure 1. A triangular fuzzy number.

Concept 3. [29] Let $\tilde{y}=\left(y_{1}, y_{2}, y_{3}\right)$ and $\tilde{z}=\left(z_{1}, z_{2}, z_{3}\right)$ be two triangular fuzzy numbers (see Fig. 2). The mathematical formulas can be defined as:

$$
\begin{aligned}
& 1 . \tilde{y}+\tilde{z}=\left(y_{1}+z_{1}, y_{2}+z_{2}, y_{3}+z_{3}\right) \\
& 2 . \tilde{z}-\tilde{y}=\left(z_{1}-y_{1}, z_{2}-y_{2}, z_{3}-y_{3}\right)
\end{aligned}
$$


Transport and Communications Science Journal, Vol. 71, Issue 4 (05/2020), 403-418

3. $\tilde{y} \times \tilde{z}=\left(y_{1} z_{1}, y_{2} z_{2}, y_{3} z_{3}\right)$

$$
\text { 4. } \beta \tilde{y}=\left(\beta y_{1}, \beta y_{2}, \beta y_{3}\right), \beta>0 ; \beta \in R
$$

$5 . \tilde{y}^{-1}=\left(\frac{1}{y_{1}}, \frac{1}{y_{2}}, \frac{1}{y_{a}}\right)$

$$
\text { 6. } \tilde{y} / \tilde{z}=\left(\frac{y_{1}}{z_{1}}, \frac{y_{2}}{z_{z}}, \frac{y_{3}}{z_{a}}\right)
$$

7.

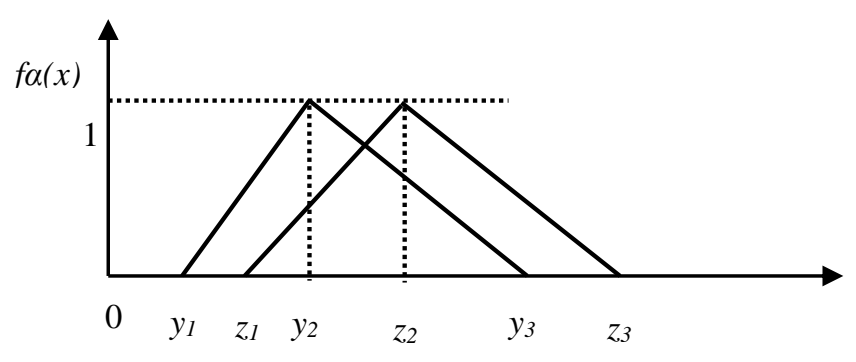

Figure 2. Two triangular fuzzy number.

Concept 4. Let $\tilde{y}=\left(y_{1}, y_{2}, y_{3}\right)$ and $\tilde{u}=\left(z_{1}, z_{2}, z_{3}\right)$ be two triangular fuzzy numbers (see Fig. 2). The distance between $\tilde{v}$ and $\tilde{u}$ is determined as follow $[38,39,36]$

$$
d(\tilde{y}, \tilde{z})=\sqrt{\frac{1}{3}\left[\left(y_{1}-z_{1}\right)^{2}+\left(y_{2}-z_{2}\right)^{2}+\left(y_{3}-z_{3}\right)^{2}\right]}
$$

\subsubsection{Establish linguistic variable}

A linguistic variable is a variable in a natural language via the judgment of decisionmakers but not numbers. Linguistic variables can be then transformed into fuzzy numbers. A fuzzy number is a fuzzy matrix, featured by a given interval of real numbers. In this study, a transformation scale of 1- 9 will be installed to assess the influence of the facets in PPP project performance evaluation [39]. Table 2 and Table 3 present the linguistic term and fuzzy numbers for rating of the criteria and each stages in project life-cycle, respectively.

Table 2. Linguistic variables for assessing the importance of success criteria.

\begin{tabular}{lc}
\hline \hline Linguistic variables & Transformation scale \\
\hline Very low $(\mathrm{VL})$ & $(1,1,3)$ \\
\hline Low $(\mathrm{L})$ & $(1,3,5)$ \\
\hline Medium $(\mathrm{M})$ & $(3,5,7)$ \\
\hline High $(\mathrm{H})$ & $(5,7,9)$ \\
\hline Very high $(\mathrm{VH})$ & $(7,9,9)$ \\
\hline \hline
\end{tabular}

Table 3. Linguistic variables for assessing the importance of criteria for each project.

\begin{tabular}{lc}
\hline Linguistic variables & Transformation scale \\
\hline Very poor (VP) & $(1,1,3)$ \\
\hline Poor $(\mathrm{P})$ & $(1,3,5)$ \\
\hline Medium $(\mathrm{F})$ & $(3,5,7)$ \\
\hline Good $(\mathrm{G})$ & $(5,7,9)$ \\
\hline Very good $(\mathrm{VG})$ & $(7,9,9)$ \\
\hline \hline
\end{tabular}




\subsection{Fuzzy TOPSIS}

The process of fuzzy TOPSIS is decribled as follow [39, 40, 36]

Step 1: Rating the criteria

Let assume that we have a group of decision makers with $k$ experts. The fuzzy numbers of each expert about criteria $F_{i}(i=1,2, \ldots, \mathrm{m})$ at project $P_{j}(j=1,2, \ldots, \mathrm{n})$ are denoted $\tilde{x}_{i j}^{k}=\left(a_{i j}^{k}, b_{i j}^{k}, c_{i j}^{k}\right)$ and the weight of each criteria $F_{i}$ is denoted $w_{i}(i=1,2, \ldots, m)$.

Step 2: Construct the aggregated fuzzy ratings for the criteria and the projects

The aggregated fuzzy weight $w_{i}=\left(w_{1 i}, w_{2 i}, w_{3 i}\right)$ of the criteria $F_{i}$ are defined as:

$$
w_{1 i}=\min _{k}\left\{w_{1 i}^{k}\right\}, w_{2 i}=\frac{1}{K} \sum_{k=1}^{K} w_{2 i}^{k}, w_{3 i}=\max _{k}\left\{w_{3 i}^{k}\right\}
$$

Where,

$K=$ total members of group.

The aggregated fuzzy numbers $\tilde{x}_{i j}^{k}=\left(a_{i j}^{k}, b_{i j}^{k}, c_{i j}^{k}\right)$ of $i^{\text {th }}$ criteria within each project are given as:

$$
a_{i j}=\min _{k}\left\{w_{i j}^{k}\right\}, b_{i j}=\frac{1}{K} \sum_{k=1}^{K} b_{i j}^{k}, c_{i j}=\max _{k}\left\{c_{i j}^{k}\right\}
$$

Step 3: Establish the normalized fuzzy decision matrix:

The normalized fuzzy desision matrix for the $k^{\text {th }}$ decision maker can be established as follow:

$$
\widetilde{R}^{k}=\left[r_{i j}^{k}\right]_{m \times n^{\prime}} k=1,2, \ldots, K ; \quad i=1,2, \ldots, m ; j=1,2, \ldots, n
$$

Where:

$$
\begin{gathered}
r_{i j}^{k}=\left(\frac{a_{i j}}{c_{j}^{*}}, \frac{b_{i j}}{c_{j}^{*}}, \frac{c_{i j}}{c_{j}^{*}}\right), \quad c_{j}^{*}=\max _{i} c_{i j} \quad \begin{array}{c}
\text { (If } i^{t h} \text { criteria is a } \\
\text { benefit one) }
\end{array} \\
r_{i j}^{k}=\left(\frac{a_{j}^{-}}{c_{i j}}, \frac{a_{j}^{-}}{b_{i j}}, \frac{a_{j}^{-}}{a_{i j}}\right), \quad a_{j}^{-}=\min _{i} a_{i j} \quad \begin{array}{c}
\text { (If } i^{t h} \text { criteria is a } \\
\text { cost one) }
\end{array}
\end{gathered}
$$

Step 4: Install the weighted normalized matrix

The weighted normalized decision matrix is conducted as:

$$
V^{k}=\left[v_{i j}^{k}\right]_{m \times n}, k=1,2, \ldots, K_{s} \quad i=1,2, \ldots, m ; j=1,2, \ldots, n \quad \text { Where: } v_{i j}^{k}=r_{i j}^{k} \times w_{j}
$$

Step 5: Calculate the Fuzzy Positive Ideal Solution (FPIS) and the Fuzzy Negative Ideal Solution (FNIS) 
Transport and Communications Science Journal, Vol. 71, Issue 4 (05/2020), 403-418

The FPIS $\left(A^{+}\right)$and FNIS $\left(A^{-}\right)$are determined as follow:

$$
\begin{aligned}
& A^{+}=\left(v_{1}^{+}, v_{2}^{+}, \ldots, v_{n}^{+}\right), \quad \text { where } v_{j}^{+}=\max _{i}\left\{v_{i j a}\right\} ; i=1,2, \ldots, m ; j=1,2, \ldots, n \\
& A^{-}=\left(v_{1}^{-}, v_{2}^{-}, \ldots, v_{n}^{-}\right), \quad \text { where } v_{j}^{-}=\min _{i}\left\{v_{i j 1}\right\} ; i=1,2, \ldots, m ; j=1,2, \ldots, n
\end{aligned}
$$

Step 6: Determine the distance of each phase from FPIS and FNIS

The distance $\left(d_{i}^{+}, d_{i}^{-}\right)$of each phase from $A^{+}$and $A^{-}$is computed as:

$$
\begin{aligned}
& d_{i}^{+}=\sum_{j=1}^{n} d\left(v_{i j}^{k}, v_{j}^{+}\right), \quad i=1,2, \ldots, m ; j=1,2, \ldots, n \\
& d_{i}^{-}=\sum_{j=1}^{n} d\left(v_{i j}^{k}, v_{j}^{-}\right), \quad i=1,2, \ldots, m ; j=1,2, \ldots, n
\end{aligned}
$$

Where $d(\tilde{l}, \tilde{p})$ represents the distance between two fuzzy number $\hat{l}$ and $\tilde{p}$.

Step 7: Calcualate the closeness coefficient $\left(C C_{i}\right)$ of each project

The closeness coefficient $C C_{i}$ is defined as :

$$
C C_{i}=\frac{d_{i}^{-}}{d_{i}^{+}+d_{i}^{-}} ; \quad C C_{i} \in[0,1], \quad i=1,2, \ldots, m
$$

Step 8: Rank the importance index of the projects

The projects are ranked based on the descending results of $C C_{i}$. The projects which has result of the biggest $C C_{i}$ value are considered as the most successful project.

\section{APPLICATION}

\subsection{Case studies for measuring the success level of PPP transport projects}

A set of success criteria is exploited in the previous section. In order to demonstrate the application of those criteria in the PPP market, the authors have examined three case studies. Output to be analyzed in each case study is the success index which is evaluated based on success criteria using the fuzzy TOPSIS technique. Table 4 shows the background of these cases.

Table 4. Background of case studies.

\begin{tabular}{lccc}
\hline \hline & $\begin{array}{c}\text { Ha Noi - Lao } \\
\text { Cai } \\
\text { (Case 1) }\end{array}$ & $\begin{array}{c}\text { Ha Noi - Ninh } \\
\text { Binh } \\
(\text { Case 2) }\end{array}$ & $\begin{array}{c}\text { TpHCM - Long Thanh - Dau } \\
\text { Giay } \\
\text { (Case 3) }\end{array}$ \\
\hline Type of project & Expressway & Expressway & Expressway \\
\hline Procurement & PPP & PPP & PPP \\
\hline Location & North Vietnam & North Vietnam & Southeast Vietnam \\
\hline Commencement day & September 2009 & April 2006 & October 2009 \\
\hline Construction time & 65 months & 77 months & 64 months \\
\hline Length & $245 \mathrm{~km}$ & $50 \mathrm{~km}$ & $55 \mathrm{~km}$ \\
\hline Speed & $120 \mathrm{~km} / \mathrm{h}$ & $120 \mathrm{~km} / \mathrm{h}$ & $120 \mathrm{~km} / \mathrm{h}$ \\
\hline Total of budget & $30.132 \mathrm{billion}$ & $8.974 \mathrm{billion}$ VND & $20.630 \mathrm{billion} \mathrm{VND}$ \\
\hline \hline
\end{tabular}


Transport and Communications Science Journal, Vol. 71, Issue 4 (05/2020), 403-418

\subsection{Classifying the success criteria}

This is a first step for further analysis of fuzzy TOPSIS method. They can be indicated in Table 5.

Table 5 showed that the criterion SC11, SC12 and SC14 are the cost (C) criteria (i.e., the lower is the better). The remaining criteria are the benefit (B) criteria (i.e., the higher is the better).

Table 5. Success criteria of PPP projects.

\begin{tabular}{llll}
\hline Criteria & Code & Definition & Type \\
\hline $\begin{array}{l}\text { Local economic } \\
\text { development }\end{array}$ & SC1 & $\begin{array}{l}\text { Creating jobs, improving infrastructure and managing local } \\
\text { resources. }\end{array}$ & B \\
\hline Long-term partnership & SC2 & $\begin{array}{l}\text { Strengthening the relationship between public and private } \\
\text { sectors }\end{array}$ & B \\
\hline $\begin{array}{l}\text { Minimized contract } \\
\text { disputes }\end{array}$ & SC3 & $\begin{array}{l}\text { Minimizing the contract disputes in the project } \\
\text { implementation }\end{array}$ & B \\
\hline Equitable legal system & SC4 & $\begin{array}{l}\text { Assuring transparency and positivity of legal framework for } \\
\text { PPP implementation }\end{array}$ & B \\
\hline Stakeholder satisfaction & SC5 & Sastifying the needs of the stakeholders & B \\
\hline Environment impact & SC6 & $\begin{array}{l}\text { The effect of the construction and operation of the project } \\
\text { on the environment }\end{array}$ & B \\
\hline $\begin{array}{l}\text { Reliable and quality } \\
\text { service }\end{array}$ & SC7 & $\begin{array}{l}\text { Providing the project services according to the satisfaction } \\
\text { of users }\end{array}$ & B \\
\hline Productivity & SC8 & Ability to achieve performance objectives & B \\
\hline Technology transfer & SC9 & Sharing the technical innovation among the stakeholders & B \\
\hline Health and safety & SC10 & $\begin{array}{l}\text { The competion of a project without major accidents of } \\
\text { injuries }\end{array}$ & B \\
\hline Profitability & SC11 & The total revenues over total costs & C \\
\hline Achieving VfM & SC12 & $\begin{array}{l}\text { Optimizing whole life cost and quality to meet the user's } \\
\text { requirement }\end{array}$ & C \\
\hline $\begin{array}{l}\text { Effective risk } \\
\text { management }\end{array}$ & SC13 & $\begin{array}{l}\text { Identifying and sharing risks effectively by the public and } \\
\text { private parties }\end{array}$ & B \\
\hline Completion in budget & SC14 & $\begin{array}{l}\text { Costs for implementing project which adherent to be lower } \\
\text { than the estimated cost }\end{array}$ & C \\
\hline \hline
\end{tabular}

\subsection{Ranking success index of case studies}

A group of four decision-makers (see in Table 6) is interviewed to rate the importance of 15 criteria for evaluating the success of three projects by using the conversion scale in Table 2, 3. For example, a decision-maker (DM1) rates the important level of SC1 for success measurement in PPP projects of 'high', the conversation scale is defined by $(5,7,9)$, respectively. Similarly, the sastifactory level of SC1 in P1 is 'good', the conversation scale is defined by $(5,7,9)$, respectively. The results of the respondents are shown in Table 7,8 . 
Transport and Communications Science Journal, Vol. 71, Issue 4 (05/2020), 403-418

Table 6. Background of decision makers.

\begin{tabular}{cccc}
\hline $\begin{array}{c}\text { Decision } \\
\text { maker }\end{array}$ & Type of organization & Position of organization & Experience \\
\hline DM1 & Public sector & Project Manager & $\geq 10$ years \\
\hline DM2 & Private sector & Researcher & $\geq 10$ years \\
\hline DM3 & Private sector & Director & $\geq 10$ years \\
\hline DM4 & Public sector & Project Manager & $\geq 10$ years \\
\hline \hline
\end{tabular}

Using Microsoft Excel 2016, the aggregated fuzzy weight $w_{i}=\left(w_{1 i}, w_{2 i}, w_{3 i}\right)$ for each criterion is first determined by Eq. (9). For example, for criterion SC1, the aggregated fuzzy weight $w_{1}=\left(w_{11}, w_{21}, w_{31}\right)$ is shown as:

$w_{11}=\min _{k}\{5,5,5,7\}=5, w_{21}=\frac{1}{3} \sum_{k=1}^{4}(7+7+7+9)=7.50, w_{21}=\max _{k}\{9,9,9,9\}=9 ; w_{1}=(5,7.50,9)$

The aggregated fuzzy weights of remaining criteria are similarly evaluated and presented in Table 7.

Likewise, the aggregated fuzzy weight $\tilde{x}_{i j}^{k}=\left(a_{i j}^{k}, b_{i j}^{k}, c_{i j}^{k}\right)$ for $i^{\text {th }}$ criteria within each project is defined by Eq. (10). For example, the aggregated fuzzy weight for SC1 of case 1 are shown as:

$a_{11}=\min _{i}\{5,5,5,7\}=5, b_{11}=\frac{1}{3} \sum_{k=1}^{4}(7+7+7+9)=7.50, \quad c_{11}=\max _{i}\{9,9,9,9\}=9 ; \tilde{x}_{11}=(5,7.50,9)$

The aggregated fuzzy weights of remaining criteria in three case studies P1, P2, and P3 are similarly calculated in Table 8.

Table 7. Linguistic rating for the importance of fifteen criteria in PPP projects.

\begin{tabular}{|c|c|c|c|c|c|}
\hline \multirow[t]{2}{*}{ Criteria } & \multicolumn{4}{|c|}{ Decision makers } & \multirow[t]{2}{*}{ Aggregate fuzzy weights } \\
\hline & DM1 & DM2 & DM3 & DM4 & \\
\hline SC1 & $(5,7,9)$ & $(5,7,9)$ & $(5,7,9)$ & $(7,9,9)$ & $(5,7.50,9)$ \\
\hline $\mathrm{SC} 2$ & $(7,9,9)$ & $(3,5,7)$ & $(3,5,7)$ & $(5,7,9)$ & $(3,6.50,9)$ \\
\hline $\mathrm{SC} 3$ & $(5,7,9)$ & $(5,7,9)$ & $(5,7,9)$ & $(5,7,9)$ & $(5,7.00,9)$ \\
\hline SC4 & $(7,9,9)$ & $(7,9,9)$ & $(7,9,9)$ & $(7,9,9)$ & $(7,9.00,9)$ \\
\hline SC5 & $(5,7,9)$ & $(5,7,9)$ & $(5,7,9)$ & $(7,9,9)$ & $(5,7.50,9)$ \\
\hline SC6 & $(7,9,9)$ & $(3,5,7)$ & $(7,9,9)$ & $(5,7,9)$ & $(3,7.50,9)$ \\
\hline SC7 & $(5,7,9)$ & $(5,7,9)$ & $(3,5,7)$ & $(5,7,9)$ & $(3,6.50,9)$ \\
\hline SC8 & $(5,7,9)$ & $(5,7,9)$ & $(7,9,9)$ & $(5,7,9)$ & $(5,7.50,9)$ \\
\hline SC9 & $(5,7,9)$ & $(7,9,9)$ & $(3,5,7)$ & $(5,7,9)$ & $(3,7.00,9)$ \\
\hline SC10 & $(5,7,9)$ & $(5,7,9)$ & $(3,5,7)$ & $(5,7,9)$ & $(3,6.50,9)$ \\
\hline SC11 & $(5,7,9)$ & $(5,7,9)$ & $(5,7,9)$ & $(5,7,9)$ & $(5,7.00,9)$ \\
\hline $\mathrm{SC} 12$ & $(5,7,9)$ & $(7,9,9)$ & $(7,9,9)$ & $(7,9,9)$ & $(5,8.50,9)$ \\
\hline SC13 & $(5,7,9)$ & $(5,7,9)$ & $(5,7,9)$ & $(7,9,9)$ & $(5,7.50,9)$ \\
\hline SC14 & $(3,5,7)$ & $(5,7,9)$ & $(7,9,9)$ & $(7,9,9)$ & $(3,7.50,9)$ \\
\hline SC15 & $(5,7,9)$ & $(7,9,9)$ & $(7,9,9)$ & $(5,7,9)$ & $(5,8.00,9)$ \\
\hline
\end{tabular}


Transport and Communications Science Journal, Vol. 71, Issue 4 (05/2020), 403-418

Table 8. Linguistic rating for the sastifactory level of criteria in three projects.

\begin{tabular}{|c|c|c|c|c|c|c|}
\hline \multirow[t]{2}{*}{ Criteria } & \multirow[t]{2}{*}{ Cases } & \multicolumn{4}{|c|}{ Decision makers } & \multirow[t]{2}{*}{ Aggregate fuzzy weights } \\
\hline & & DM1 & DM2 & DM3 & DM4 & \\
\hline \multirow{3}{*}{ SC1 } & P1 & $(5,7,9)$ & $(5,7,9)$ & $(5,7,9)$ & $(7,9,9)$ & $(5,7.50,9)$ \\
\hline & $\mathrm{P} 2$ & $(5,7,9)$ & $(5,7,9)$ & $(5,7,9)$ & $(5,7,9)$ & $(5,7.00,9)$ \\
\hline & $\mathrm{P} 3$ & $(5,7,9)$ & $(7,9,9)$ & $(5,7,9)$ & $(7,9,9)$ & $(5,8.00,9)$ \\
\hline \multirow{3}{*}{$\mathrm{SC} 2$} & $\mathrm{P} 1$ & $(1,3,5)$ & $(5,7,9)$ & $(5,7,9)$ & $(5,7,9)$ & $(1,6.00,9)$ \\
\hline & $\mathrm{P} 2$ & $(3,5,7)$ & $(5,7,9)$ & $(3,5,7)$ & $(5,7,9)$ & $(3,6.00,9)$ \\
\hline & $\mathrm{P} 3$ & $(3,5,7)$ & $(3,5,7)$ & $(3,5,7)$ & $(3,5,7)$ & $(3,5.00,7)$ \\
\hline \multirow{3}{*}{$\mathrm{SC} 3$} & $\mathrm{P} 1$ & $(3,5,7)$ & $(5,7,9)$ & $(3,5,7)$ & $(5,7,9)$ & $(3,6.00,9)$ \\
\hline & $\mathrm{P} 2$ & $(3,5,7)$ & $(5,7,9)$ & $(3,5,7)$ & $(5,7,9)$ & $(3,6.00,9)$ \\
\hline & $\mathrm{P} 3$ & $(5,7,9)$ & $(3,5,7)$ & $(3,5,7)$ & $(3,5,7)$ & $(3,5.00,9)$ \\
\hline \multirow{3}{*}{$\mathrm{SC} 4$} & $\mathrm{P} 1$ & $(3,5,7)$ & $(5,7,9)$ & $(5,7,9)$ & $(5,7,9)$ & $(3,6.50,9)$ \\
\hline & $\mathrm{P} 2$ & $(3,5,7)$ & $(5,7,9)$ & $(3,5,7)$ & $(5,7,9)$ & $(3,6.00,9)$ \\
\hline & $\mathrm{P} 3$ & $(3,5,7)$ & $(3,5,7)$ & $(3,5,7)$ & $(3,5,7)$ & $(3,5.00,7)$ \\
\hline \multirow{3}{*}{ SC5 } & $\mathrm{P} 1$ & $(1,3,5)$ & $(5,7,9)$ & $(5,7,9)$ & $(5,7,9)$ & $(1,6.00,9)$ \\
\hline & $\mathrm{P} 2$ & $(3,5,7)$ & $(5,7,9)$ & $(3,5,7)$ & $(5,7,9)$ & $(3,6.00,9)$ \\
\hline & $\mathrm{P} 3$ & $(5,7,9)$ & $(3,5,7)$ & $(5,7,9)$ & $(3,5,7)$ & $(3,6.00,9)$ \\
\hline \multirow{3}{*}{ SC6 } & $\mathrm{P} 1$ & $(3,5,7)$ & $(5,7,9)$ & $(3,5,7)$ & $(5,7,9)$ & $(3,6.00,9)$ \\
\hline & $\mathrm{P} 2$ & $(3,5,7)$ & $(5,7,9)$ & $(3,5,7)$ & $(5,7,9)$ & $(3,6.00,9)$ \\
\hline & $\mathrm{P} 3$ & $(5,7,9)$ & $(1,3,5)$ & $(5,7,9)$ & $(3,5,7)$ & $(1,5.50,9)$ \\
\hline \multirow{3}{*}{ SC7 } & $\mathrm{P} 1$ & $(5,7,9)$ & $(5,7,9)$ & $(3,5,7)$ & $(5,7,9)$ & $(3,6.50,9)$ \\
\hline & $\mathrm{P} 2$ & $(5,7,9)$ & $(3,5,7)$ & $(3,5,7)$ & $(5,7,9)$ & $(3,6.00,9)$ \\
\hline & $\mathrm{P} 3$ & $(3,5,7)$ & $(3,5,7)$ & $(3,5,7)$ & $(3,5,7)$ & $(3,5.00,7)$ \\
\hline \multirow{3}{*}{ SC8 } & $\mathrm{P} 1$ & $(3,5,7)$ & $(5,7,9)$ & $(3,5,7)$ & $(5,7,9)$ & $(3,6.00,9)$ \\
\hline & $\mathrm{P} 2$ & $(3,5,7)$ & $(5,7,9)$ & $(3,5,7)$ & $(5,7,9)$ & $(3,6.00,9)$ \\
\hline & $\mathrm{P} 3$ & $(5,7,9)$ & $(3,5,7)$ & $(5,7,9)$ & $(3,5,7)$ & $(3,6.00,9)$ \\
\hline \multirow{3}{*}{ SC9 } & $\mathrm{P} 1$ & $(3,5,7)$ & $(5,7,9)$ & $(3,5,7)$ & $(5,7,9)$ & $(3,6.00,9)$ \\
\hline & $\mathrm{P} 2$ & $(3,5,7)$ & $(3,5,7)$ & $(3,5,7)$ & $(5,7,9)$ & $(3,5.50,9)$ \\
\hline & P3 & $(5,7,9)$ & $(3,5,7)$ & $(3,5,7)$ & $(5,7,9)$ & $(3,6.00,9)$ \\
\hline \multirow{3}{*}{ SC10 } & $\mathrm{P} 1$ & $(3,5,7)$ & $(5,7,9)$ & $(3,5,7)$ & $(5,7,9)$ & $(3,6.00,9)$ \\
\hline & $\mathrm{P} 2$ & $(3,5,7)$ & $(5,7,9)$ & $(3,5,7)$ & $(5,7,9)$ & $(3,6.00,9)$ \\
\hline & P3 & $(5,7,9)$ & $(3,5,7)$ & $(5,7,9)$ & $(3,5,7)$ & $(3,6.00,9)$ \\
\hline \multirow{3}{*}{ SC11 } & $\mathrm{P} 1$ & $(3,5,7)$ & $(5,7,9)$ & $(3,5,7)$ & $(5,7,9)$ & $(3,6.00,9)$ \\
\hline & $\mathrm{P} 2$ & $(3,5,7)$ & $(5,7,9)$ & $(3,5,7)$ & $(5,7,9)$ & $(3,6.00,9)$ \\
\hline & P3 & $(7,9,9)$ & $(5,7,9)$ & $(5,7,9)$ & $(5,7,9)$ & $(5,7.50,9)$ \\
\hline \multirow{3}{*}{$\mathrm{SC} 12$} & $\mathrm{P} 1$ & $(5,7,9)$ & $(5,7,9)$ & $(5,7,9)$ & $(5,7,9)$ & $(5,7.00,9)$ \\
\hline & $\mathrm{P} 2$ & $(3,5,7)$ & $(5,7,9)$ & $(3,5,7)$ & $(5,7,9)$ & $(3,6.00,9)$ \\
\hline & P3 & $(5,7,9)$ & $(7,9,9)$ & $(5,7,9)$ & $(5,7,9)$ & $(5,7.50,9)$ \\
\hline \multirow{3}{*}{ SC13 } & $\mathrm{P} 1$ & $(3,5,7)$ & $(5,7,9)$ & $(5,7,9)$ & $(3,5,7)$ & $(3,6.00,9)$ \\
\hline & $\mathrm{P} 2$ & $(3,5,7)$ & $(5,7,9)$ & $(3,5,7)$ & $(5,7,9)$ & $(3,6.00,9)$ \\
\hline & $\mathrm{P} 3$ & $(3,5,7)$ & $(3,5,7)$ & $(5,7,9)$ & $(3,5,7)$ & $(3,5.50,9)$ \\
\hline \multirow{3}{*}{ SC14 } & $\mathrm{P} 1$ & $(1,3,5)$ & $(5,7,9)$ & $(3,5,7)$ & $(5,7,9)$ & $(1,5.50,9)$ \\
\hline & $\mathrm{P} 2$ & $(1,3,5)$ & $(5,7,9)$ & $(3,5,7)$ & $(3,5,7)$ & $(1,5.00,9)$ \\
\hline & P3 & $(3,5,7)$ & $(3,5,7)$ & $(3,5,7)$ & $(7,9,9)$ & $(3,6.00,9)$ \\
\hline \multirow{3}{*}{ SC15 } & $\mathrm{P} 1$ & $(3,5,7)$ & $(5,7,9)$ & $(3,5,7)$ & $(3,5,7)$ & $(3,5.50,9)$ \\
\hline & $\mathrm{P} 2$ & $(1,3,5)$ & $(5,7,9)$ & $(3,5,7)$ & $(3,5,7)$ & $(1,5.00,9)$ \\
\hline & P3 & $(5,7,9)$ & $(1,3,5)$ & $(3,5,7)$ & $(3,5,7)$ & $(1,5.00,9)$ \\
\hline
\end{tabular}

The normalized fuzzy decision matrix of three projects will be conducted in the next step by Eqs. (11) - (13). For example, the normalized value of SC1 (benefit criteria) in P1 is 
Transport and Communications Science Journal, Vol. 71, Issue 4 (05/2020), 403-418

calculated as follows:

$$
r_{21}=\left[\frac{5}{9}, \frac{7.50}{9}, \frac{9}{9}\right]=[0.56,0.83,1.00], \quad c_{j}^{*}=\max _{i}\{9,9,9\}
$$

In constract, the normalized value of SC11 (cost criteria) in $\mathrm{P} 1$ is given by as follows:

$$
r_{11}=\left[\frac{3}{9}, \frac{3}{6.00}, \frac{3}{3}\right]=[0.33,0.50,1.00], \quad a_{j}^{-}=\min _{i}\{3,3,5\}=3
$$

All the normalized values at each stage are shown in Table 9.

Table 9. Normalized fuzzy decision matrix.

\begin{tabular}{cccc}
\hline \hline \multirow{2}{*}{ Criteria } & P1 & Cases & P2 \\
\cline { 2 - 4 } & {$[0.56,0.83,1.00]$} & {$[0.56,0.78,1.00]$} & {$[0.56,0.89,1.00]$} \\
\hline SC1 & {$[0.11,0.67,1.00]$} & {$[0.33,0.67,1.00]$} & {$[0.33,0.56,0.78]$} \\
\hline SC2 & {$[0.33,0.67,1.00]$} & {$[0.33,0.67,1.00]$} & {$[0.33,0.61,1.00]$} \\
\hline SC3 & {$[0.33,0.72,1.00]$} & {$[0.33,0.67,1.00]$} & {$[0.33,0.56,0.78]$} \\
\hline SC4 & {$[0.11,0.67,1.00]$} & {$[0.33,0.67,1.00]$} & {$[0.33,0.67,1.00]$} \\
\hline SC5 & {$[0.33,0.67,1.00]$} & {$[0.33,0.67,1.00]$} & {$[0.11,0.61,1.00]$} \\
\hline SC6 & {$[0.33,0.72,1.00]$} & {$[0.33,0.67,1.00]$} & {$[0.33,0.56,0.78]$} \\
\hline SC7 & {$[0.33,0.67,1.00]$} & {$[0.33,0.67,1.00]$} & {$[0.33,0.67,1.00]$} \\
\hline SC8 & {$[0.33,0.67,1.00]$} & {$[0.33,0.61,1.00]$} & {$[0.33,0.67,1.00]$} \\
\hline SC9 & {$[0.33,0.67,1.00]$} & {$[0.33,0.67,1.00]$} & {$[0.33,0.67,1.00]$} \\
\hline SC10 & {$[0.33,0.50,1.00]$} & {$[0.33,0.50,1.00]$} & {$[0.33,0.40,0.60]$} \\
\hline SC11 & {$[0.33,0.43,0.60]$} & {$[0.33,0.50,1.00]$} & {$[0.33,0.40,0.60]$} \\
\hline SC12 & {$[0.33,0.67,1.00]$} & {$[0.33,0.67,1.00]$} & {$[0.33,0.61,1.00]$} \\
\hline SC13 & {$[0.11,0.18,1.00]$} & {$[0.11,0.20,1.00]$} & {$[0.11,0.17,0.33]$} \\
\hline SC14 & {$[0.33,0.61,1.00]$} & {$[0.11,0.56,1.00]$} & {$[0.11,0.56,1.00]$} \\
\hline SC15 & &
\end{tabular}

The fuzzy weighted decision matrix $\tilde{V}^{k}$ is conducted by Eq. (6.14). Whereby, $r_{i j}^{k}$ and $w_{i}$ values were given in Table 7 and Table 9, respectively. Taking SC2 of P2 is an example, the fuzzy weighted value is computed as:

$$
v_{22}=[0.33,0.67,1.00] \times(3,6.50,9)=[1.00,4.33,9.00]
$$

Similarly, the remaining criteria are presented in Table 10.

\begin{tabular}{|c|c|c|c|c|c|}
\hline \multirow{2}{*}{ Criteria } & \multicolumn{3}{|c|}{ Cases } & \multirow{2}{*}{ FPIS(+) } & \multirow{2}{*}{ FPNS(-) } \\
\hline & P1 & P2 & $\mathbf{P 3}$ & & \\
\hline $\mathrm{SC} 1$ & {$[2.78,6.25,9.00]$} & {$[2.78,5.83,9.00]$} & {$[2.78,6.67,9.00]$} & $(9,9,9)$ & $(2.78,2.78,2.78)$ \\
\hline $\mathrm{SC} 2$ & {$[0.33,4.33,9.00]$} & {$[1.00,4.33,9.00]$} & {$[1.00,3.61,7.00]$} & $(9,9,9)$ & $(0.33,0.33,0.33)$ \\
\hline $\mathrm{SC} 3$ & {$[1.67,4.67,9.00]$} & {$[1.67,4.67,9.00]$} & {$[1.67,4.28,9.00]$} & $(9,9,9)$ & $(1.67,1.67,1.67)$ \\
\hline SC4 & {$[2.33,6.50,9.00]$} & {$[2.33,6.00,9.00]$} & {$[2.33,5.00,7.00]$} & $(9,9,9)$ & $(2.33,2.33,2.33)$ \\
\hline SC5 & {$[0.56,5.00,9.00]$} & {$[1.67,5.00,9.00]$} & {$[1.67,5.00,9.00]$} & $(9,9,9)$ & $(0.56,0.56,0.56)$ \\
\hline SC6 & {$[1.00,5.00,9.00]$} & {$[1.00,5.00,9.00]$} & {$[0.33,4.58,9.00]$} & $(9,9,9)$ & $(0.33,0.33,0.33)$ \\
\hline SC7 & {$[1.00,4.69,9.00]$} & {$[1.00,4.33,9.00]$} & {$[1.00,3.61,7.00]$} & $(9,9,9)$ & $(1.00,1.00,1.00)$ \\
\hline SC8 & {$[1.67,5.00,9.00]$} & {$[1.67,5.00,9.00]$} & {$[1.67,5.00,9.00]$} & $(9,9,9)$ & $(1.67,1.67,1.67)$ \\
\hline SC9 & {$[1.00,4.67,9.00]$} & {$[1.00,4.28,9.00]$} & {$[1.00,4.67,9.00]$} & $(9,9,9)$ & $(1.00,1.00,1.00)$ \\
\hline SC10 & {$[1.00,4.33,9.00]$} & {$[1.00,4.33,9.00]$} & {$[1.00,4.33,9.00]$} & $(9,9,9)$ & $(1.00,1.00,1.00)$ \\
\hline SC11 & {$[1.67,3.50,9.00]$} & {$[1.67,3.50,9.00]$} & {$[1.67,2.80,5.40]$} & $(9,9,9)$ & $(1.67,1.67,1.67)$ \\
\hline $\mathrm{SC} 12$ & {$[1.67,3.64,5.40]$} & {$[1.67,4.25,9.00]$} & {$[1.67,3.40,5.40]$} & $(9,9,9)$ & $(1.67,1.67,1.67)$ \\
\hline SC13 & {$[1.67,5.00,9.00]$} & {$[1.67,5.00,9.00]$} & {$[1.67,4.58,9.00]$} & $(9,9,9)$ & $(1.67,1.67,1.67)$ \\
\hline SC14 & {$[0.33,1.36,9.00]$} & {$[0.33,1.50,9.00]$} & {$[0.33,1.25,3.00]$} & $(9,9,9)$ & $(0.33,0.33,0.33)$ \\
\hline SC15 & {$[1.67,4.89,9.00]$} & {$[0.56,4.44,9.00]$} & {$[0.56,4.44,9.00]$} & $(9,9,9)$ & $(0.56,0.56,0.56)$ \\
\hline
\end{tabular}

Using Eqs. (15) and (16), FPIS and FPNS are then calculated and shown in Table 10.

Table 10. Weighted fuzzy decision matrix, FPIS, and FPNS. 
Transport and Communications Science Journal, Vol. 71, Issue 4 (05/2020), 403-418

The distance of each criterion from FPIS(+) and FPNS(-) can be then determined based on Eq. (8). For example, the distances of SC5 of P1 is given as follows:

$$
\begin{gathered}
d_{v}\left(P_{1}, A^{+}\right)=\sqrt{\frac{(0.56-9)^{2}+(5.00-9)^{2}+(9.00-9)^{2}}{3}}=5.395 \\
d_{v}\left(P_{1}, A^{-}\right)=\sqrt{\frac{(0.56-0.56)^{2}+(5.00-0.56)^{2}+(9.00-0.56)^{2}}{3}}=5.506
\end{gathered}
$$

The distances for the remaining criteria at three phases are similarly shown in Table 11.

Table 11. The distance measurement.

\begin{tabular}{ccccccc}
\hline \hline Criteria & $\boldsymbol{d}_{\boldsymbol{v}}\left(\boldsymbol{P}_{\mathbf{1}}, \boldsymbol{A}^{+}\right)$ & $\boldsymbol{d}_{\boldsymbol{v}}\left(\boldsymbol{P}_{\mathbf{2}}, \boldsymbol{A}^{+}\right)$ & $\boldsymbol{d}_{\boldsymbol{v}}\left(\boldsymbol{P}_{\mathbf{3}}, \boldsymbol{A}^{+}\right)$ & $\boldsymbol{d}_{\boldsymbol{v}}\left(\boldsymbol{P}_{\mathbf{1}}, \boldsymbol{A}^{-}\right)$ & $\boldsymbol{d}_{\boldsymbol{v}}\left(\boldsymbol{P}_{\mathbf{2}}, \boldsymbol{A}^{-}\right)$ & $\boldsymbol{d}_{\boldsymbol{v}}\left(\boldsymbol{P}_{\boldsymbol{3}}, \boldsymbol{A}^{-}\right)$ \\
\hline SC1 & 3.928 & 4.031 & 3.837 & 4.112 & 4.000 & 4.235 \\
\hline SC2 & 5.683 & 5.347 & 5.687 & 5.513 & 5.527 & 4.309 \\
\hline SC3 & 4.918 & 4.918 & 5.036 & 4.572 & 4.572 & 4.492 \\
\hline SC4 & 4.111 & 4.221 & 4.635 & 4.542 & 4.395 & 3.106 \\
\hline SC5 & 5.395 & 4.823 & 4.823 & 5.506 & 5.543 & 5.543 \\
\hline SC6 & 5.164 & 5.164 & 5.616 & 5.699 & 5.699 & 5.576 \\
\hline SC7 & 5.245 & 5.347 & 5.687 & 5.088 & 5.004 & 3.778 \\
\hline SC8 & 4.823 & 4.823 & 4.823 & 4.648 & 4.648 & 4.648 \\
\hline SC9 & 5.253 & 5.363 & 5.253 & 5.081 & 4.991 & 5.081 \\
\hline SC10 & 5.347 & 5.347 & 5.347 & 5.004 & 5.004 & 5.004 \\
\hline SC11 & 5.292 & 5.292 & 5.921 & 4.362 & 4.362 & 2.250 \\
\hline SC12 & 5.640 & 5.044 & 5.718 & 2.436 & 4.486 & 2.374 \\
\hline SC13 & 4.823 & 4.823 & 4.942 & 4.648 & 4.648 & 4.554 \\
\hline SC14 & 6.669 & 6.617 & 7.554 & 5.041 & 5.051 & 1.630 \\
\hline SC15 & 4.854 & 5.540 & 5.540 & 5.514 & 5.364 & 5.364 \\
\hline$\sum d_{v}$ & 77.144 & 76.701 & 80.419 & 71.765 & 73.295 & 61.943 \\
\hline \hline
\end{tabular}

Based on values of $d_{i}^{+}$and $d_{\tilde{i}}^{-}$, the closeness coefficient $C C_{\tilde{i}}$ of three stages are defined by Eq. (19). The final result is shown in Table 12.

Table 12. Distances $d_{i}^{+}, d_{i}^{-}$, and closeness coefficient $C C_{i}$ over PPP project.

\begin{tabular}{lccccc}
\hline \hline & $P_{1}$ & $P_{2}$ & $P_{3}$ & Ranking \\
\hline$d_{i}^{+}$ & 77.144 & 76.701 & 80.419 & \\
\cline { 1 - 4 }$d_{i}^{-}$ & 71.765 & 25.944 & 61.943 & \\
\cline { 1 - 5 }$C C_{i}$ & 0.482 & 0.489 & 0.435 & \\
\hline \hline
\end{tabular}

The results of Table 12 indicated that project 2 is considered as the most successful with a satisfactory degree of 0.489 . Project 1 and project 3 are ranked second and third with a satisfactory degree of 0.482 and 0.435 , respectively.

Project 2, namely Ha Noi - Ninh Binh Expressway is an important part of the North-South Expressway project. The project contributes to increased transport capacity and creates opportunity connectivity with spiritual tourism destinations, scenic parks, and historic sites in North Vietnam. Since opened traffic, it serves more than 18 million CPU safely and efficient circulation, approximately 16,500 CPU/day. Each year rise by more than 5 million vehicles circulating on the roads. Saving $15 \%$ on transport simultaneously. 
The second-ranking is Ha Noi - Lao Cai Expressway, this project has brought positive effects, promoting the socio-economic development in the Northwest region, facilitating the economic restructuring of ethnic minorities. In addition, it also creates the connection of economic centers, industrial parks, tourism and entertainment in North Vietnam. The transport duration from Hanoi to Lao Cai has been reduced to 3.5 hours compared to the previous 7 hours, saving $10 \%$ of transport costs.

The last-ranking is Ho Chi Minh City - Long Thanh - Dau Giay Expressway. This project is a part of the North-South Expressway, located in the Southern Focal Economic Area, which is one of the most dynamic regions and make the greatest contribution to the national economy. This project will reduce the travel time from Ho Chi Minh city, Mekong River Delta and Central Highland. This route is the key factor to promote the potential of tourism and entertainment; create the connectivity among the industrial zones, ports, and airports, and enhance the socio-economic development of the provinces in the South region of Vietnam. Ho Chi Minh - Long Thanh - Dau Giay Expressway put into operation has reduced the traveling route by $20 \mathrm{~km}$ and the traveling time just for about 01 hours (faster by 02 hours than before). Currently, the Expressway has served 4.5 million traffic flows, approximately 15,000 CPU/day. The route helps to save $10 \%$ of transportation costs.

\section{CONLUSION}

Project success has been interested in a long time by many authors. However, it is diverse and ambiguous due to various perceptions. Most of the studies have considered the success of PPP project in general, not in specific review. Using fuzzy TOPSIS, this study assessed the success index of specific case studies in Vietnam with 15 identified criteria. Although they were judged as effective by experts' opinions. Nevertheless, the success index of these expressway project still lower than 0.5 . Therefore, project managers need to propose effective strategies to enhance the success index of these projects in the future.

Although this study remains limited. This result can help participants to be a good insight into the project success in expressway projects in developing countries in general and Vietnam in particular. Whereby, it enriches the scholar documentation about the success criteria for PPP projects.

\section{REFERENCES}

[1]. A. Akintoye, C. Hardcastle, M. Beck, E. Chinyio, D. Asenova, Achieving best value in private finance initiative project procurement, Construction Management and Economics, 21 (2003) 461 - 470. http://doi.org/10.1080/0144619032000087285

[2]. E. Skietrys, A. Raipa, E.V. Bartkus, Dimensions of the efficiency of the public - private partnership, $\quad$ Engineering $\quad$ Economics, $58 \quad \begin{array}{lllll}58 & \text { (2008) } & 3 & - & 45 .\end{array}$ http://inzeko.ktu.lt/index.php/EE/article/view/11542

[3]. R. Osei - Kyei, A.P.C. Chan, Review of studies on the Critical Success Factors for Public - Private Partnership (PPP) projects from 1990 to 2013, International Journal of Project Management, 33 (2015) 1335 - 1346. http://doi.org/10.1016/j.ijproman.2015.02.008

[4]. T.D. Sy, V. Likhitruangsilp, M. Onishi, T.P. Nguyen, Impacts of risk factors on the performance of Public-Private Partnership transportation projects in Vietnam, ASEAN Eng. J., 7 (2017) 30-52. 
Transport and Communications Science Journal, Vol. 71, Issue 4 (05/2020), 403-418

[5]. S.O. Ogunlana, Build operate transfer procurement traps: examples from transportation projects in Thailand, Paper presented in Proceedings of CIB W92 on Procurement, IF Research Corporation, Montreal, 1997.

[6]. A. Davies, M. Moore, No way out of tunnel torture, Sydney Morning Herald, 21 October 2005.

[7]. J.J.A.M. Reijniers, Organization of Public - Private Partnership projects: the timely prevention of pitfalls, International Journal of Project Management, 12 (1994) 137 - 142. https://doi.org/10.1016/0263-7863(94)90028-0

[8]. Y. Ke, S.Q. Wang, A.P.C. Chan, E. Cheung, Research trend of Public - Private Partnership in Construction Journals, Journal of Construction Engineering and Management, 135 (2009) 1076 - 1086. https://doi.org/10.1061/(ASCE)0733-9364(2009)135:10(1076)

[9]. U. Ahamd, Y.B. Ibrahim, A.B.A. Bakar, Malaysian Public Private Partnership projects: Project success definition, International Journal of Engineering \& Technology, 7 (2018) 3337. https://doi.org/10.14419/ijet.v7i3.30.18151

[10]. A. Hodge, C. Greve, Public Private Partnership: An internatinal performance review. Public Administration Review, 67 (2007) 545-558. https://doi.org/10.1111/j.1540$\underline{6210.2007 .00736 . x}$

[11]. R. Osei-Kyei, A.P.C. Chan, Comparative analysis of the success criteria for Public Private Partnership projects in Ghana and Hong Kong, Project Management Journal, 48 (2017) 80-92. https://doi.org/10.1177/875697281704800407

[12]. L.A. Ika, Project success as a topic in project management journal, Project Management Journal, 40 (2009) 6-19. https://doi.org/10.1002/pmj.20137

[13]. A.P.C. Chan, A.P.L. Chan, Key performance indicators for measuring construction success, Benchmarking: An International Journal, $11 \quad(2004) 203 \quad$ - 221. https://doi.org/10.1108/14635770410532624

[14]. S.M.H.M. Al-Tmeemy, H.A. Rahman, Z. Harun, Future criteria for success of building projects in Malaysia. International Journal of Project Management, 29 (2011), 337 - 348. https://doi.org/10.1016/j.ijproman.2010.03.003

[15]. A.P.C. Chan, D. Scott, E.W.M. Lam, Framework of success criteria for design/build projects, Journal of Management in Engineering, 18 (2002) $120 \quad-128$. https://doi.org/10.1061/(ASCE)0742-597X(2002)18:3(120)

[16]. A.M.M. Liu, A. Walker, Evaluation of project outcomes, Construction Management and Economics, 16 (1998) 209 - 219. https://doi.org/10.1080/014461998372493

[17]. S. Zhang, A.P.C. Chan, Y. Feng, H. Duan, Y. Ke, Crirical review on PPP Research - A search from the Chinese and International Journals, International Journal of Project Management, 34 (2016) 597 - 612. https://doi.org/10.1016/j.ijproman.2016.02.008

[18]. C.M. Tam, Build - Operate - Transfer model for infrastructure developments in Asia: reasons for success and failures, International Journal of Project Management, 17 (1999) 377 - 382. https://doi.org/10.1016/S0263-7863(98)00061-1

[19]. J. Yuan, A.Y. Zeng, M.J. Skibniewski, Q. Li, Selection of performance objectives and key performance indicators in public - private partnership projects to achieve value for money, Construction Management and Economics, 27 (2009) 253 - 270. 
https://doi.org/10.1080/01446190902748705

[20]. G. Mladenovic, N. Vajdic, B. Wundsch, A. Temeljotov-Salaj, Use of key performance indicators for PPP transport projects to meet stakeholders' performance objectives, Built Environment Project and Asset Management, 3 (2013) 228 - 249. https://doi.org/10.1108/BEPAM-05-2012-0026

[21]. F. Villalba-Romero, C. Liyanage, Evaluating success in PPP road projects in Europe: a comparison of performance measurement approachs, Transportation Research Procedia, 14 (2016) 372 - 381. https://doi.org/10.1016/j.trpro.2016.05.089

[22]. C. Liyanage, F. Villalba-Romero, Measuring success of PPP transport projects: A crosscase analysis of toll roads, Transport Review, 35 (2015) 140 - 161. https://doi.org/10.1080/01441647.2014.994583

[23]. M. Zayyanu, F. Johar, Measuring the success of Public - Private Partnership projects: a conceptual framework. Journal of Built Environment, Technology and Engineering, 2 (2017) 90 - 98. https://doi.org/10.1166/asl.2017.10038

[24]. C.S. Lim, M.Z. Mohamed, Criteria of project success: an exploratory re-examination. International Journal of Project Management, $17 \quad(1999) 243-248$. https://doi.org/10.1016/S0263-7863(98)00040-4

[25]. D.K. Ahadzie, D.G. Proverbs, P.O. Olomolaiye, Critical success criteria for mass house building projects in developing countries, International Journal of Project Management, 26 (2008) 675 - 687. https://doi.org/10.1016/j.ijproman.2007.09.006

[26]. D. Baccarini, The logical framework method for defining project success, Project Management Journal, 30 (1999) 25 - 32. https://doi.org/10.1177/875697289903000405

[27]. J. Liu, P.E.D. Love, M.C.P. Sing, J. Smith, J. Matthews, PPP Social Infrastructure Procurement: Examining the Feasibility of a Lifecycle Performance Measurement Framework, Journal of Infrastructure System, $23 \quad$ (2017) 04016041. https://doi.org/10.1061/(ASCE)IS.1943-555X.0000347

[28]. R. Kangari, L.S. Riggs, Construction risk assessment by linguistic, IEEE Transactions on Engineering Management, 36 (1989) 126 - 131. https://doi.org/10.1109/17.18829

[29]. S. Nădăban, S. Dzitac, I. Dzitac, Fuzzy TOPSIS: A general review, Procedia Computer Science, 91 (2016) 823 - 831. https://doi.org/10.1016/j.procs.2016.07.088

[30]. R.E. Bellman, L.A. Zadeh, Decision-making in a fuzzy environment, Management Science, 17 (1970) 141 - 164. https://doi.odg/10.1287/mnsc.17.4.B141

[31]. A.V. Thomas, S.N. Kalidindi, L.S., Ganesh, Modelling and assessment of critical risks in BOT road projects, Construction Management and Economics, 24 (2006) 407 - 424. https://doi.org/10.1080/01446190500435275.

[32]. Y. Xu, J.F.Y. Yeung, A.P.C. Chan, D.W.M. Chan, S.Q. Wang, Y. Ke, Developing a risk assessment model for PPP in China - A fuzzy synthetic evaluation approach, Autom. Constr., 19 (2010) 929 - 943. https://doi.org/10.1016/j.autcon.2010.06.006.

[33]. M.S.Islam, M. P. Nepal, M. Skitmore, M. Attarzadeh, Current research trend and application areas of fuzzy and hybrid methods to risk assessment of construction projects, $\begin{array}{lllll}\text { Advanced } \quad \text { Engineering } \quad \text { Infomatics, } & 33 \quad \text { (2017) }\end{array}$ https://doi.org/10.1016/j.aei.2017.06.001 
Transport and Communications Science Journal, Vol. 71, Issue 4 (05/2020), 403-418

[34]. A.I. Maghsoodi, M. Khalilzadeh, Identification and evaluation of construction projects critical success factors employing fuzzy-TOPSIS approach, KSCE Journal of Cilvil Engineering, 22 (2018) 1593 - 1605. https://doi.org/10/1007/s12205-017-1970-2

[35]. Y.T. Tan, L.Y. Shen, C. Langston, Y. Liu, Construction project selection using fuzzy TOPSIS approach, Journal of Modelling in Management, 5 (2010) 302 - 315, https://doi.org/10.1108/17465661011092669

[36]. A.R.K. Azari, N. Mousavi, S.F. Mousavi, S.B. Hosseini, Risk assessment model selection in construction industry, Expert System with Applications, 38 (2011) 9105 - 9111. https://doi.org/10.1016/j.eswa.2010.12.110

[37]. Zimmermann, H.J., Fuzzy Set Theory and its application, $4^{\text {th }}$ ed., Kluwer Academic, Boston, MA, 2001.

[38]. S. Heilpern, Representation and application of fuzzy numbers, Fuzzy Sets and Systems, 91 (1997) 259- 268, https://doi.org/10.1016/S0165-0114(97)00146-2

[39]. A. Awasthi, S.S. Chauhan, S.K. Goyal, A multi-criteria decision making approach for location planning for urban distribution centers under uncertainty, Mathematical and Computer Modelling, 53 (2011) 98 - 109. https://doi.org/10.1016/j.mcm.2017.07.023

[40]. C.T. Chen, Extension of the TOPSIS for group decision-making under fuzzy environment, Fuzzy Sets and Systems, 114 (2000) 1 - 9. https://doi.org/10.1016/S0165$\underline{0114(97) 00377-1}$ 